\title{
Molecular aspects of bovine cystic ovarian disease pathogenesis
}

\author{
Hugo H Ortega ${ }^{1,2}$, Belkis E Marelli ${ }^{1,2}$, Florencia Rey ${ }^{1,2}$, Ayelen N Amweg ${ }^{1,2}$, Pablo U Díaz ${ }^{1,2}$, \\ Matías L Stangaferro ${ }^{3,4}$ and Natalia R Salvetti ${ }^{1,2}$ \\ ${ }^{1}$ Laboratorio de Biología Celular y Molecular Aplicada, Facultad de Ciencias Veterinarias, Universidad Nacional \\ del Litoral, R P Kreder 2805, 3080 Esperanza, Santa Fe, Argentina, ${ }^{2}$ Instituto de Ciencias Veterinarias del Litoral \\ (ICiVet-Litoral), Consejo Nacional de Investigaciones Científicas y Tecnológicas (CONICET), Esperanza, \\ Santa Fe, Argentina, ${ }^{3}$ Cátedra de Teriogenología, Facultad de Ciencias Veterinarias, Universidad Nacional del Litoral, \\ Esperanza, Santa Fe, Argentina and ${ }^{4}$ Department of Animal Science, College of Agriculture and Life Sciences, \\ Cornell University, Ithaca, New York, USA
}

Correspondence should be addressed to H H Ortega; Email: hhortega@fcv.unl.edu.ar

\begin{abstract}
Cystic ovarian disease (COD) is one of the main causes of reproductive failure in cattle and causes severe economic loss to the dairy farm industry because it increases both days open in the post partum period and replacement rates due to infertility. This disease is the consequence of the failure of a mature follicle to ovulate at the time of ovulation in the estrous cycle. This review examines the evidence for the role of altered steroid and gonadotropin signaling systems and the proliferation/apoptosis balance in the ovary with cystic structures. This evidence suggests that changes in the expression of ovarian molecular components associated with these cellular mechanisms could play a fundamental role in the pathogenesis of COD. The evidence also shows that gonadotropin receptor expression in bovine cystic follicles is altered, which suggests that changes in the signaling system of gonadotropins could play a fundamental role in the pathogenesis of conditions characterized by altered ovulation, such as COD. Ovaries from animals with COD exhibit a disrupted steroid receptor pattern with modifications in the expression of coregulatory proteins. These changes in the pathways of endocrine action would trigger the changes in proliferation and apoptosis underlying the aberrant persistence of follicular cysts. Free Spanish abstract: A Spanish translation of this abstract is freely available at http://www.reproduction-online.org/content/149/6/ R251/suppl/DC1.

Reproduction (2015) 149 R251-R264
\end{abstract}

\section{Introduction}

Cystic ovarian disease (COD), which is an important cause of infertility in dairy cattle, has been defined as the presence of one or more follicles of more than $20 \mathrm{~mm}$ in diameter in the ovaries, persisting for up to 10 days without luteal tissue, interrupting the normal reproductive cycle (Silvia et al. 2002). The incidence of COD in dairy herds has been reported to vary from 5 to $30 \%$ (Vanholder et al. 2006, Cattaneo et al. 2014) and this condition generates significant economic losses to the dairy industry because it increases the calving-to-conception and inter-calving intervals (Peter 2004).

The etiopathogenesis of COD in dairy cattle is a complex process that involves dysfunctions in various physiological processes, including folliculogenesis, steroidogenesis, and ovulation, and many factors, such as stress, herd management, nutritional status, body condition, and infectious disease, can coexist (Silvia et al. 2002). Although it is accepted that the central component of the etiopathogenesis of COD is associated with an altered function of the hypothalamus-pituitaryovarian axis, the persistence of follicles over time is linked to an important intraovarian component (Silvia et al. 2002). The ovulatory failure leads to cyst development and persistence in the ovary, interfering with the normal ovarian function (Vanholder et al. 2006). Some authors define persistence as a temporal stage of the life span of the cyst (Cook et al. 1990, Hamilton et al. 1995), whereas others define it as a separate follicular pathology (Mihm et al. 1994).

Intraovarian alterations, as contributors to follicular persistence, have not yet been clearly established. However, several studies have contributed to a better understanding of specific aspects related to the pathogenesis of COD. In relation to endocrine signaling pathways, some of these studies have demonstrated altered expression of steroid and gonadotropin receptors (Salvetti et al. 2007, 2012, Marelli et al. 2014). Other studies have postulated and tested the intrafollicular 
roles of steroids in regulating follicular development (Berisha et al. 2002, Gümen \& Wiltbank 2005, Salvetti et al. 2007, 2012).

In addition, it has been previously demonstrated that the proliferation/apoptosis balance in follicles from animals with COD is altered. These follicles show diminished cell proliferation and apoptosis in situ and decreased expression of pro-apoptotic proteins relative to antiapoptotic proteins (Salvetti et al. 2009, 2010). The proliferation of granulosa cells and the fate of follicles (degeneration by follicular atresia or cystic development) are specifically related to steroid hormone and gonadotropin receptors. The imbalance between proliferation and apoptosis found in follicular cysts could explain the development of cystic follicles and the preservation of a static condition without atresia, which leads to their persistence. These alterations may be due to structural and functional changes that could be related to the hormonal milieu and take place in the follicles of animals with COD. In relation to cellular changes, it has been proposed that follicular cysts represent a distinctive stage of follicular differentiation, with a characteristic protein and gene expression profile in ovarian cells that differs from that found in dominant follicles or other follicular categories (Ortega et al. 2007, Salvetti et al. 2010, 2012, Velázquez et al. 2010, 2011, Matiller et al. 2014).

This review examines evidences for the role of altered gonadotropin and steroid signaling systems and the proliferation/apoptosis balance in the ovary from animals with COD. These data suggest that changes in the expression of ovarian molecular components associated with these cellular mechanisms could play a fundamental role in the pathogenesis of the disease.

\section{Expression of gonadotropin receptors}

Follicular growth and steroidogenesis depend on the coordinated interaction between gonadotropins and their receptors in granulosa and theca cells. The cellular mechanisms regulating folliculogenesis, ovulation, and follicular regression in cows are not fully defined. However, a key role of gonadotropins in the regulation of follicular development has been well established (Nogueira et al. 2007, Nimz et al. 2009). In normal ovaries, the interactive system of follicular growth and steroidogenesis suggests that granulosa and theca cells are involved in the secretion of steroid hormones through the two-cell/two-gonadotropin model (Fortune \& Quirk 1988). In this model, granulosa cells possess membrane receptors to follicle-stimulating hormone (FSHR) and theca cells contain receptors to luteinizing hormone/ choriogonadotropin (LHCGR) during the earlier stages of follicular development (Bao \& Garverick 1998). As follicular development progresses, changes occur within the dominant follicle that is preparing for ovulation. Among these changes, the acquisition of LHCGR by the granulosa cells of the dominant follicle and the increase in the aromatization of androgens provided by the theca cells in response to $\mathrm{LH}$ and FSH are some of the most important changes (Wiltbank et al. 2002).

As mentioned earlier in this review, neuroendocrinological dysfunction of the hypothalamic-pituitary-gonadal axis is the most accepted hypothesis related to the formation of cystic follicles (Liptrap \& McNally 1976, Kesler \& Garverick 1982, Garverick 1997, Vanholder et al. 2006). It has been demonstrated that gonadotropin regulation of bovine FSHR and LHCGR protein content during follicular growth, ovulation, and luteinization is associated with analogous changes in their respective receptor mRNA levels (Soumano et al. 1998). Gonadotropin receptors are structurally related members of the seven transmembrane domain G protein-associated receptor superfamily (Vassart et al. 2004). The gene encoding LHCGR contains 11 exons (Segaloff et al. 1990, Segaloff \& Ascoli 1993), while that encoding FSHR contains ten exons (Rajapaksha et al. 1996, Hillier 2001). It has also been demonstrated that LHCGR and FSHR mRNAs are highly alternatively spliced (Figs 1 and 2; Rajapaksha et al. 1996, Simoni et al. 1997, Robert et al. 2003, Kawate 2004, Nogueira et al. 2010). However, there are no investigations of splice variants in ovarian follicular cysts.

The distribution pattern and expression levels of gonadotropin receptors in healthy ovaries have been evaluated by several methods, including conventional and real-time RT-PCR, northern blot assays, and in situ hybridization (Ireland \& Roche 1983, Xu et al. 1995, Bodensteiner et al. 1996, Rajapaksha et al. 1996, Bao et al. 1997, Evans \& Fortune 1997, Bao \& Garverick 1998, Soumano et al. 1998, Odore et al. 1999, Calder et al. 2001, Manikkam et al. 2001, Robert et al. 2003, Braw-Tal \& Roth 2005, Luo \& Wiltbank 2006, Mihm et al. 2006, Nogueira et al. 2007, Nimz et al. 2009). In recent studies conducted in our laboratory, we analyzed the relative expression levels of LHCGR and FSHR in follicular cysts of cows with COD and antral follicles of healthy animals by real-time RT-PCR and, in agreement with that found by other authors, we found that mRNA

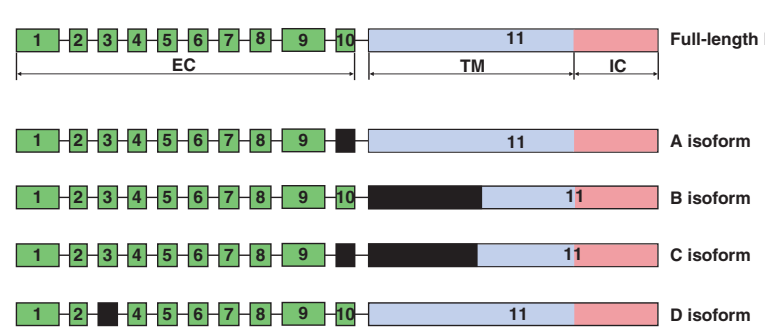

Figure 1 Schematic diagram of the alignment for the different isoforms of the luteinizing hormone/choriogonadotropin receptor (LHCGR). Exons 1 through 10 code for the extracellular ligand-binding domain (EC), while exon 11 codes for the transmembrane (TM) and intracellular (IC) domains. On the different isoforms, solid black boxes represent missing portions. 

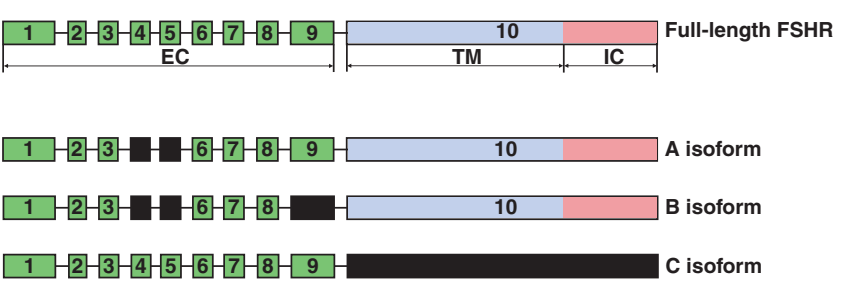

Figure 2 Schematic diagram of the alignment for the different isoforms of the follicle-stimulating hormone receptor (FSHR). Exons 1 through 9 code for the extracellular ligand-binding domain (EC), while exon 10 codes for the transmembrane (TM) and intracellular (IC) domains. On the different isoforms, solid black boxes represent missing portions.

expression of FSHR in antral follicles was exclusively localized to granulosa cells and it decreased as follicle size increased, and that LHCGR mRNA was detected in theca cells of antral follicles of all sizes and in the granulosa cells of large antral follicles, being theca cells of medium antral follicles, the ones that showed the highest expression (Marelli et al. 2014). In cattle, Xu et al. (1995) detected FSHR mRNA in follicles with less than three layers of granulosa cells, and Beg et al. (2001) demonstrated that LHCGR mRNA was higher in granulosa cells from the largest follicle than in those from the second largest follicle of the follicular wave, before morphological deviation, suggesting that the capacity of granulosa cells to respond to LH is part of the deviation process.

The results of our analysis of the mRNA expression of gonadotropin receptors (Marelli et al. 2014) agree with previous studies demonstrating that LHCGR expression in granulosa cells from bovine follicles smaller than $8 \mathrm{~mm}$ in diameter is absent or not detectable (Ginther et al. 1996, Sartori et al. 2001). These studies have demonstrated that follicles smaller than $8 \mathrm{~mm}$ in diameter are independent of gonadotropin support, whereas follicles larger than this diameter require endogenous LH to develop. Therefore, follicles are considered to be $\mathrm{FSH}$ dependent until dominance occurs, after which they become LH dependent (Fortune et al. 2001, Ginther et al. 2001, Garverick et al. 2002). In this sense, LHCGR expression in granulosa cells has been detected by in situ hybridization in follicles of more than $9 \mathrm{~mm}$ in diameter that become dominant (Xu et al. 1995, Bao et al. 1997, Garverick et al. 2002), together with higher binding of hCG to granulosa cells in dominant follicles (Ireland \& Roche 1983). It must also be considered that LHCGR mRNA levels in granulosa cells of the dominant follicle are higher than those of subordinate follicles (Beg et al. 2001, Evans et al. 2004). Moreover, in agreement with Mihm et al. (2006), our findings (Marelli et al. 2014) support the hypothesis that the dominant follicle presents a decrease in FSH dependence and an increase in $\mathrm{LH}$ dependence as it grows during the low FSH environment of follicular waves.
Several studies have evaluated the possible alterations in the expression of gonadotropin receptors as a component of COD etiopathogenesis, but, currently, there is controversy concerning this issue. Hormonal binding assays suggest that the amounts of FSHR and LHCGR in granulosa cells of cysts are lower than those in normal antral follicles (Kawate et al. 1990). However, studies using the same binding assay, but with a different sample preparation, have shown that LHCGR and FSHR concentrations in the follicular cysts are similar to those observed in control follicles (Odore et al. 1999). Calder et al. (2001) compared LHCGR and FSHR mRNA expression by in situ hybridization in ovaries from cows with dominant and non-dominant ovarian follicular cysts and in healthy dominant follicles and found that LHCGR mRNA expression was higher in granulosa cells of dominant follicular cysts than in dominant follicles, without differences in theca cells, and without differences in FSHR mRNA expression. Discrepancies between studies may be partly explained by differences in the methodology used, such as the determination of the receptor itself or its mRNA, and the classification of cysts into estrogenactive and estrogen-inactive (Vanholder et al. 2006). These differences may also be because some authors study the whole follicular wall, while others analyze the granulosa and theca cells separately.

Stimulation of the hypothalamic-pituitary-adrenal/ ovarian axis by stress disrupts the reproductive function and could be associated with bovine COD pathogenesis (Moberg 1987). Altered folliculogenesis, reduced ovulation rates, and follicular cyst development have been reported in association with adrenocorticotropic hormone (ACTH) administration and increased levels of glucocorticoids (Liptrap \& McNally 1976, Liptrap 1993, Kawate et al. 1996, Dobson et al. 2000, Amweg et al. 2013). In this sense, Kawate et al. (2001) proposed stress as a potential mechanism for the development of bovine follicular cysts. First, ACTH stimulates the release of cortisol and progesterone, and then an increased secretion of progesterone inhibits the release of gonadotropin-releasing hormone. Enhanced secretion of cortisol decreases estradiol secretion and LHCGR content in antral follicles. As a result of these hormonal imbalances, the positive feedback action of estradiol on the hypothalamus and pituitary is worsened and the LH surge is suppressed. Finally, ovulation does not occur and the follicle becomes cystic. This proposed mechanism agrees with the decreased expression of LHCGR reported both by Kawate (2004) and our group (Marelli et al. 2014).

\section{The intraovarian steroid pathway}

\section{Steroid receptors}

Steroid hormones play a critical role in folliculogenesis as well as in ovarian development and differentiation. 
The main hormones involved in these processes are androgens, estrogens, and progesterone (Rosenfeld et al. 2001, Drummond et al. 2002, Schams \& Berisha 2002, Brosens 2004, Drummond 2006, Kimura et al. 2007, Ortega et al. 2009). Steroid hormones act through specific receptors that are members of a superfamily of ligand-dependent transcriptional activators, which directly regulate the expression of specific gene complexes involved in regulating the differentiation and growth of reproductive tissues, as well as other metabolic processes (Brosens 2004). In mammals, two subtypes of the estrogen receptor (ESR) have been identified, ESR1 and ESR2. These are related structurally but encoded by two distinct genes (Kuiper et al. 1996). The progesterone receptor (PGR), instead, has different isoforms that originate from the same gene (PGRA, PGRB, and PGRC) (Wei et al. 1990, Bramley 2003). Finally, androgens perform their actions by binding to the androgen receptor (AR), which is presented in at least two isoforms (ARA and $A R B$ ) originated from the same gene (Takeo \& Yamashita 1999, Brinkmann 2001).

The location of steroid hormone receptors in the ovarian follicle has been evaluated by many authors and in different species (Manikkam et al. 2001, Cassar et al. 2002, Jo et al. 2002, Schams \& Berisha 2002, Van den Broeck et al. 2002a,b, Hampton et al. 2004, D'Haeseleer et al. 2005). It has been previously demonstrated that a subtle imbalance in the expression of the two subtypes of ESR in the components of the ovarian follicle could be involved in the pathogenesis of follicular cysts in cattle (Garverick 1997, Salvetti et al. 2007, 2012, Alfaro et al. 2012), sheep (Ortega et al. 2009), humans (Shushan et al. 1996, Jakimiuk et al. 2002), and rodents (Salvetti et al. 2009).

In addition, studies on cows with COD induced by the administration of ACTH have evidenced changes only in the expression of ESR2 in cystic follicles compared with control follicles, partially coinciding with the findings in animals with spontaneous disease (Salvetti et al. 2007, 2012, Alfaro et al. 2012). Studies have also demonstrated an increase in ESR1 expression in animals with spontaneous COD and not in the experimental model, differences that are probably due to the persistence time of the cysts (Salvetti et al. 2012). Other authors have found analogous modifications in the expression of ESR2 in cysts from women with polycystic ovarian syndrome related to normal-size follicles (Jakimiuk et al. 2002) and in prenatal testosterone-treated sheep characterized by an abnormal follicular persistence (Ortega et al. 2009).

ESR1 and ESR2 bind to $17 \beta$-estradiol with highaffinity dimerization between them, forming hetero- or homodimers. In this context, estrogen-dependent transcriptional activity varies according to the cell type, the promoter, and the types of dimers formed (Mclnerney et al. 1998, Pettersson et al. 2000). Therefore, expression of ESR2 in specific cells could regulate the responsiveness to estrogens in certain target genes in a cell-dependent mode (O'Brien et al. 1999). Previous studies have demonstrated that ESR2/ESR1 heterodimers repress ESR 1 activity and the affinity to $17 \beta$-estradiol (Hall \& McDonnell 1999). Recently, it has been suggested that the main determinants of the transcriptional activity of ESR1 and ESR2 are their individual concentrations in target cells as well as the structure of the estrogen ligand and not their binding ability (Gougelet et al. 2007, Bhavnani et al. 2008). Thus, a specific ligand could exert various activities according to the ESR subtypes expressed in cells, leading to the fact that small changes in the ESR1/ESR2 ratio could alter folliculogenesis and ovulation (Mosselman et al. 1996, Pettersson et al. 1997) by altering cellular proliferation and apoptosis, the expression of hormonal receptors, and steroidogenesis, and all molecular aspects of COD (Fig. 3; Isobe \& Yoshimura 2000a, Calder et al. 2001, Salvetti et al. 2010, Marelli et al. 2014).

In relationship to AR, Hampton et al. (2004) showed that this receptor is expressed in ovarian follicles of bovines, and that its expression is increased throughout folliculogenesis, whereas Alfaro et al. (2012) found that $A R$ mRNA expression is significantly increased in granulosa cells of bovine follicular cysts. This increase would be associated with the role of androgens in follicular differentiation and growth (Hillier \& Tetsuka 1997, Vendola et al. 1998, Walters et al. 2008). Furthermore, there are discrepancies between AR mRNA and protein expression, which could be explained by post-translational regulation (Sette et al. 2010, Salvetti et al. 2012). Finally, changes in the delicate balance between the ESR subtypes, coupled with alterations in the expression of $A R$, may contribute COD development especially to the maintenance over time of the cystic structures (Ortega et al. 2008, Salvetti et al. 2010, 2012).

Previous studies have demonstrated cell-specific expression of PGR in the bovine ovary (Jo et al. 2002, Van den Broeck et al. 2002b). In our laboratory, we analyzed the expression of PGR in ovaries from cattle with COD and found different results according to the group of animals tested. In cattle with spontaneous COD from abattoirs, we detected increased mRNA levels of PGRB in theca cells (Alfaro et al. 2012), but found no differences in protein expression (Salvetti et al. 2007). On the other hand, in animals with ACTH-induced COD, we detected decreased PGR protein expression in granulosa cells of cysts, and levels similar to those of controls in theca cells (Salvetti et al. 2012). In addition, specific technical factors such as the sensitivity of the PCRs and the post-transcriptional regulation of gene expression should be considered (Anderson et al. 1992, Garverick 1997, Sette et al. 2010).

Taking into account the influence of gonadotropin and steroid hormones on PGR expression and that these hormones are altered in animals with COD (Vanholder et al. 2006, Amweg et al. 2013), it is likely that there will 


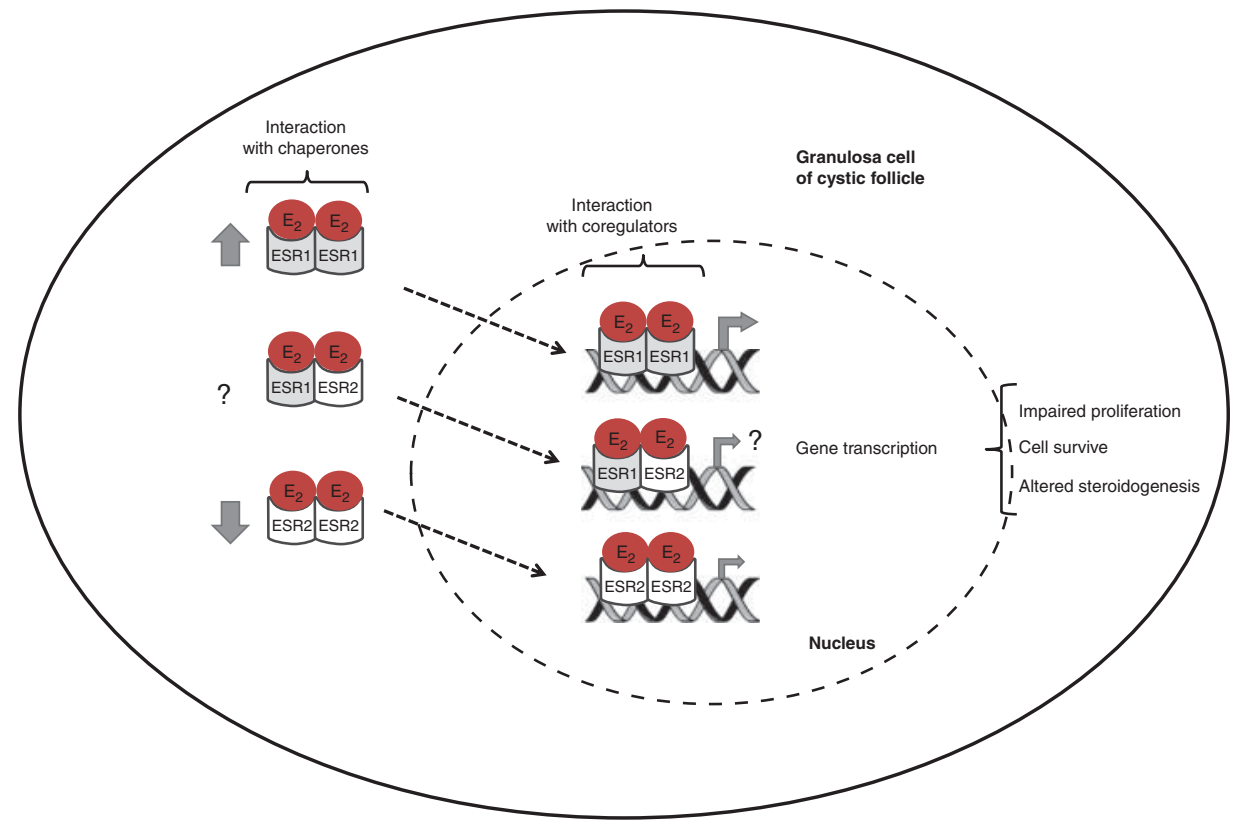

Figure 3 Estrogen and estrogen receptor (ESR) dimer interaction in granulosa cells of experimentally induced cystic follicles. Interaction between endogenous $17 \beta$-estradiol $\left(E_{2}\right)$ and chaperones allows binding to ER type $\alpha$ (ESR1) or $\beta$ (ESR2) with similar affinity and forms homo- and heterodimers. Higher levels of ESR1 and lower levels of ESR2 were detected in granulosa cells of induced cysts. Dimers are able to go through the nuclear envelope and, in the nucleus, they interact with different coregulators that modulate differential transcriptional activities in a cell- and promoter contextdependent manner.

be changes in the expression of PGR or the predominance of one isoform over another. It has been widely reported that the coexpression of PGRA or PGRC in the same kind of cell as PGRB modulates its activity (Vegeto et al. 1993, Wei et al. 1997). Moreover, the genomic actions of PGR isoforms are affected by their association with nuclear coactivators and molecular chaperones (Bramley 2003). Both PGRA and PGRB may activate different sets of genes, even within the same cell, revealing the enormous complexity of progesterone-dependent activation in the target cell (Graham \& Clarke 2002, Alfaro et al. 2012). This suggests that changes in the expression of PGR isoforms could regulate the biological activity of progesterone, resulting in functional hormone withdrawal at the ovarian level, under unchanged progesterone serum concentrations (Schams et al. 2003, Amrozi et al. 2004, Goldman et al. 2005).

\section{Steroid receptor coregulators}

The biological activity of steroid hormone receptors is determined by ligand-binding proteins and also by the relative activities of nuclear receptor-associated coregulators (Mussi et al. 2006). Moreover, the equilibrium between them and the nature of the ligand define the state of nuclear receptor activation (Park et al. 2005). Among the large number of coactivators, the most important ones are the nuclear receptor coactivator (NCOA) or steroid receptor coactivator (SRC) family, which includes NCOA1 (SRC1), NCOA2 (SRC2/GRIP1/ TIF2), and NCOA3 (SRC3/pCIP/ACTR/AIB1/RAC3/ TRAM1) (McKenna et al. 1999). Mostly, NCOA3 acts as a coregulator for steroid receptors and affects a large number of signaling systems that are essential for normal cell physiology (Wu et al. 2002, Yang et al. 2006). In contrast to the function of NCOAs, corepressors generally suppress or silence gene transcription (Auger \& Jessen 2009). Nuclear receptor corepressor 2 (NCOR2/SMRT), which was discovered through its interaction with thyroid and retinoid hormone receptors, is one of the most widely studied corepressors (Chen \& Evans 1995, Hörlein et al. 1995). Another important corepressor is the repressor of ESR activity (REA), which interacts with ESR among others (Montano et al. 1999, Delage-Mourroux et al. 2000). These corepressors are thought to decrease gene transcription by attenuating steroid receptor activity by recruiting class I and II histone deacetylases, which modify chromatin into a transcriptionally silent status (Kurtev et al. 2004), and by competing with coactivators for binding to receptors in the presence of ligands (Martini et al. 2000).

Although the expression of coregulators has been scarcely studied in the ovary (Hlaing et al. 2001, Zhang et al. 2003, Hussein-Fikret \& Fuller 2005, Chen et al. 2008), follicular development can be influenced by an altered expression of coregulators that may lead to differential transcriptional activation of steroid receptors (Fig. 4; Delage-Mourroux et al. 2000). Under these circumstances, some hormone-dependent organs or tumors exhibit over-expression of the NCOA family members that would be directly involved in the increase in cell proliferation and differentiation, indicating their important physiological role (Sarvilinna et al. 2006, Mukherjee et al. 2007).

Considering that any change in the steroid receptor equilibrium is correlated with follicular health and the 


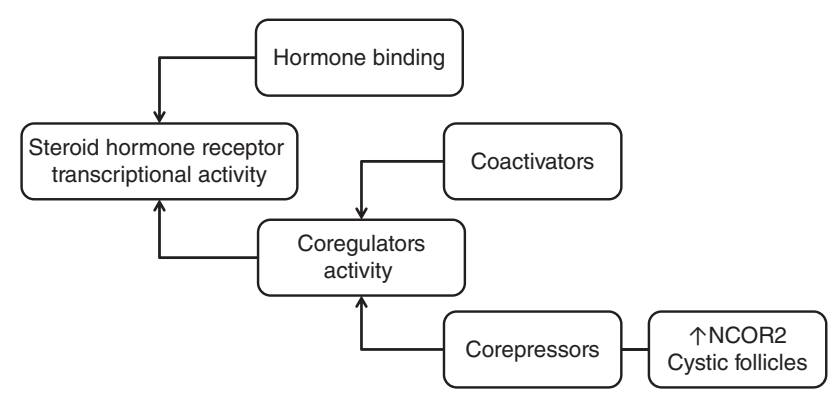

Figure 4 Transcriptional activity of steroid hormone receptors is determined by hormone binding and by the relative activities of nuclear receptor-associated coregulators, which are able to increase (coactivators) or suppress or silence gene transcription (corepressors). Higher levels of NCOR2, which could play a role as corepressors of estrogens, androgens, and progesterone, modulating the response to steroid hormones in the microenvironment affected by the imbalance in steroid receptor expression, are detected in cystic follicles.

stage of development, modifications in intrafollicular activity of steroid hormones determine the fate of a specific follicle (Rosenfeld et al. 2001, Drummond et al. 2002, Walters et al. 2008).

Studies determining the expression levels of steroid receptor coregulators in reproductive tissue are limited mainly to rodents (Misiti et al. 1998, 1999, Xu et al. 1998, Nephew et al. 2000). In domestic animals, Hlaing et al. (2001) analyzed the mRNA expression of several coregulators in the ovary of sheep, cows, and pigs by northern blot and found mRNA expression of NCOA1, NCOA2, NCOA3, p300, RIP140, SPA, and NCOR2 in follicles of the three species studied. By in situ hybridization, they localized NCOA1, RIP140, and SPA in granulosa and theca cell layers and stroma of the ovine ovary (Hlaing et al. 2001).

In previous studies of our group, we have described the localization of several nuclear receptor coregulators in normal bovine ovarian follicles as well as in follicles of animals with COD. We have demonstrated that induced COD in cattle is concurrent with alterations in the expression of steroid receptors and coregulators in ovarian follicles (Salvetti et al. 2012). We also found intense immunostaining of NCOA3 in granulosa cells of different follicle categories and an increase in its expression in theca cells of follicular cysts. Furthermore, we found a similar pattern for REA in granulosa cells. Notably, REA differs from other coregulators, in that it is highly specific for ESR, acting as a negative regulator of control ESR-dependent gene expression in normal cells (Mussi et al. 2006). On the other hand, we found that NCOR2 shows a gradual increase in its expression while folliculogenesis progresses, with greater expression in cystic follicles (Salvetti et al. 2012). These findings suggest that NCOR2 could have a role as a corepressor of sexual steroids in the ovary of animals with COD, modulating the response to these hormones in an environment of altered nuclear steroid receptor expression.
Several studies have highlighted the role of coregulators in total transcriptional activity of steroid hormone receptors (Evers et al. 2014a, Feng \& O'Malley 2014). However, most of these studies have been carried out in mammary and uterine normal tissues or tumor tissues (Evers et al. 2014a, b, Feng \& O'Malley 2014, Szwarc et al. 2014). To date, there are few studies evaluating the role of these proteins and their interactions in the ovary, and their function (Hlaing et al. 2001, Hussein-Fikret \& Fuller 2005). Overexpression of coactivator proteins may lead to increased transcriptional activation of nuclear steroid receptors, leading to an enhanced response in hormonedependent tissues. Despite the lack of information about normal expression, an amplification of NCOA3 has been observed in ovarian tumors and has been correlated with cell differentiation and tumor growth (Bautista et al. 1998, Tanner et al. 2000). On the other hand, in breast cancer, amplification of NCOA3 has been correlated with high expression levels, enhanced positivity to ESR and PGR, and an increase in tumor size, supporting the hypothesis that NCOA3 plays an important role in estrogen-dependent tumor development and progression (Anzick et al. 1997, Bautista et al. 1998). Although the information is limited, steroid receptor-associated coregulators may be involved in multiple ovarian functions such as folliculogenesis, steroidogenesis, and ovulation, and thus their altered expression adds another piece in the intricate pathogenesis of COD in cattle. However, these changes could be the consequence of follicle persistence, rather than a cause of it.

\section{Cell proliferation and survival mechanisms in follicular cysts}

During folliculogenesis, ovarian cells must follow two essential steps in order to complete follicular development: proliferation and differentiation. After follicles are established, a continuous process of proliferation and differentiation allows some of them to reach the preovulatory size (maximum differentiation level) and ovulate, but most ovarian follicles undergo a process of regression and death known as follicular atresia (Robker \& Richards 1998a,b, Adams et al. 2008).

Cell cycle kinase cascades are in charge of controlling cell cycle proliferation and progression by a complex signaling system involving positive and negative regulators (Robker \& Richards 1998a,b). Cyclins have been recognized as positive regulatory components of a class of protein kinases designated as cyclin-dependent kinases (CDKs). These protein kinases have been shown to be important regulators of major cell cycle transitions in diverse eukaryotic systems. In mammals, the process involving activation of cyclin proteins, followed by activation of their CDK partner and the phosphorylation of target proteins, plays an essential role in cell cycle transitions (Zwijsen et al. 1997). 
Table 1 Cell proliferation in cystic follicles of different species and models.

\begin{tabular}{|c|c|c|c|c|c|}
\hline Species & $\begin{array}{l}\text { Spontaneous } \\
\text { disease/model }\end{array}$ & Cell types evaluated & Methods & Results & Reference \\
\hline Rat & $\begin{array}{l}\text { Continuous light- } \\
\text { induced PCOS } \\
\text { rat model }\end{array}$ & $\begin{array}{l}\text { Granulosa, theca interna, } \\
\text { and theca externa cells of } \\
\text { tertiary, atretic, and cystic } \\
\text { follicles and complete } \\
\text { ovaries }\end{array}$ & $\begin{array}{l}\text { PCNA and Ki-67 } \\
\text { immunohistochem- } \\
\text { istry expression } \\
\text { (proliferation index) }\end{array}$ & $\begin{array}{l}\text { Granulosa and theca interna of } \\
\text { cystic follicles presented lower } \\
\text { proliferation index when } \\
\text { compared with control tertiary } \\
\text { follicles. The theca externa also } \\
\text { had reduced proliferation index } \\
\text { in atretic and cystic follicles }\end{array}$ & $\begin{array}{l}\text { Salvetti et al. } \\
\text { (2009) }\end{array}$ \\
\hline Human & Spontaneous PCOS & Granulosa cells & $\begin{array}{l}\text { Ki-67 immunocyto- } \\
\text { chemistry } \\
\text { expression } \\
\text { (proliferation index) }\end{array}$ & $\begin{array}{l}\mathrm{Ki}-67 \text { was significantly higher } \\
\text { in the PCOS group }\end{array}$ & Das et al. (2008) \\
\hline Bovine & Spontaneous COD & $\begin{array}{l}\text { Granulosa and theca cells } \\
\text { of healthy antral follicles, } \\
\text { early and late atretic ones, } \\
\text { and early and late } \\
\text { cystic ones }\end{array}$ & $\begin{array}{l}\text { PCNA immuno- } \\
\text { histochemistry } \\
\text { expression }\end{array}$ & $\begin{array}{l}\text { Lower frequencies of PCNA- } \\
\text { positive cells in cystic follicles } \\
\text { compared with healthy follicles } \\
\text { in the granulosa layer from } \\
\text { subapical to basal regions }\end{array}$ & $\begin{array}{l}\text { Isobe \& } \\
\text { Yoshimura } \\
(2000 b)\end{array}$ \\
\hline Bovine & Spontaneous COD & $\begin{array}{l}\text { Granulosa and theca cells } \\
\text { of follicular cysts }\end{array}$ & $\begin{array}{l}\text { PCNA immuno- } \\
\text { histochemistry } \\
\text { expression }\end{array}$ & $\begin{array}{l}\text { Low frequencies of PCNA-positive } \\
\text { cells in cystic follicles }\end{array}$ & $\begin{array}{l}\text { Isobe \& } \\
\text { Yoshimura } \\
\text { (2007) }\end{array}$ \\
\hline Bovine & $\begin{array}{l}\text { Adrenocorticotropin } \\
\text { (ACTH)-induced } \\
\text { COD model }\end{array}$ & $\begin{array}{l}\text { Granulosa and theca cells of } \\
\text { secondary, tertiary, atretic, } \\
\text { and cystic follicles in } \\
\text { ACTH-induced COD } \\
\text { model and synchronized } \\
\text { control cows }\end{array}$ & $\begin{array}{l}\text { Ki-67 expression by } \\
\text { immunohistochem- } \\
\text { istry and RT-PCR of } \\
\text { cyclins E and D }\end{array}$ & $\begin{array}{l}\text { Greater proliferation index in } \\
\text { granulosa cells of tertiary follicles } \\
\text { from the control group than in } \\
\text { tertiary, atretic, and cystic } \\
\text { follicles from COD group. } \\
\text { Secondary follicles from the } \\
\text { COD group exhibited an } \\
\text { elevated proliferation index }\end{array}$ & $\begin{array}{l}\text { Salvetti et al. } \\
\quad(2010)\end{array}$ \\
\hline Swine & Spontaneous COD & $\begin{array}{l}\text { Granulosa and theca cells } \\
\text { of normal, atretic, and } \\
\text { cystic follicles }\end{array}$ & $\begin{array}{l}\text { PCNA immunohisto- } \\
\text { chemistry, western } \\
\text { blot and real-time } \\
\text { PCR }\end{array}$ & $\begin{array}{l}\text { Lower proliferation activity was } \\
\text { detected in granulosa and theca } \\
\text { cells from cystic follicles, and a } \\
\text { lesser number of PCNA-positive } \\
\text { cells were found in cystic } \\
\text { follicles }\end{array}$ & Sun et al. (2012) \\
\hline
\end{tabular}

PCOS, polycystic ovary syndrome; COD, cystic ovarian disease.

The progression through the G1 phase of the cell cycle requires the action of one specific group of cyclins, D-type cyclins. In humans as well as in cows, three D-type cyclins (cyclins D1, D2, and D3) have been identified (Zwijsen et al. 1997, Yamauchi et al. 2003). Although they have different functions according to the cell type, all of them appear to act by activating CDK4 and CDK6 (Zwijsen et al. 1997, Robker \& Richards 1998a, Yamauchi et al. 2003). According to Robker \& Richards $(1998 a, b)$, the expression of cyclin D2 and CDK4 in the ovary is confined to the granulosa layer, whereas cyclin D1 and cyclin D3 are expressed in both granulosa and theca layers, with higher expression levels in theca cells. Cyclin E, another cyclin that seems to play a role in the ovary, acts as a positive regulator of cell cycle progression through activation of CDK2 (Reed 1996, Robker \& Richards 1998a).

Follicular development is an inefficient process, whereby more than $99 \%$ of the follicles present at birth are destined to degenerate during lifetime via atresia (Tilly et al. 1991). It is well documented that follicular atresia occurs by apoptosis (Hughes \& Gorospe 1991). Two of the main players involved in the apoptosis of follicular cells are the FAS system and BCL2 family members (Kim et al. 1999, Roughton et al. 1999). According to Krammer
(1999), the rate of apoptosis might be defined by the interactions between these two proteins. The binding between the FAS receptor (FAS/CD95), a member of the TNF family, and its ligands (FASLG) leads to the formation of a death-induced signaling complex (Krammer 1999, Slot et al. 2006). The BCL2 family might be divided into two main groups, according to their proapoptotic (BAX, $\mathrm{BAD}, \mathrm{BIM}, \mathrm{BclxS}$, and BOK) or antiapoptotic function (i.e., BCL2, BclxL, and BCL2L2) (Slot et al. 2006). All of them are regulatory proteins whose actions occur at the mitochondrial level. The antiapoptotic effect is achieved through the blockage of caspase 3, caspase 6 , and caspase 7 , which transduce the apoptotic signals (Tilly 1996). The penultimate stage of cell death requires caspases (Das et al. 2008). DNA repair enzymes and cytoskeletal and nuclear scaffold proteins are activated by caspase 3 (Scaffidi et al. 1998, Krammer 1999, Slot et al. 2006), which is required for apoptosis in follicular atresia. Granulosa cells, oocytes, and theca cells undergo apoptosis as part of atresia (Hsueh et al. 1994, Markstrom et al. 2002), to which early antral follicles are more sensitive (Markstrom et al. 2002).

In cows, the expression of FAS and FASLG during the first follicular wave is lower in dominant follicles than in subordinate follicles (Porter et al. 2000, 2001). 
Table 2 Apoptosis determination in cystic follicles of different species and models.

\begin{tabular}{|c|c|c|c|c|c|}
\hline Species & $\begin{array}{l}\text { Spontaneous } \\
\text { disease/model }\end{array}$ & Cell types evaluated & Methods & Results & Reference \\
\hline Rat & $\begin{array}{l}\text { DHEA-treated } \\
\text { PCOS rat model }\end{array}$ & $\begin{array}{l}\text { Granulosa cells of cystic } \\
\text { follicles }\end{array}$ & TUNEL & $\begin{array}{l}\text { Apoptosis in the granulosa cells of the } \\
\text { cumulus and those lining the antral } \\
\text { cavity of cysts but not in the outer } \\
\text { mural resting on the basement } \\
\text { membrane }\end{array}$ & $\begin{array}{l}\text { Anderson \& Lee } \\
\quad(1997)\end{array}$ \\
\hline Rat & $\begin{array}{l}\text { Continuous light- } \\
\text { induced PCOS } \\
\text { rat model }\end{array}$ & $\begin{array}{l}\text { Granulosa, theca interna, } \\
\text { and theca externa cells } \\
\text { of tertiary, atretic, and } \\
\text { cystic follicles }\end{array}$ & $\begin{array}{l}\text { TUNEL, activated caspase } \\
3 \text {, and Bcl2 family } \\
\text { member's expression by } \\
\text { immunohistochemistry }\end{array}$ & $\begin{array}{l}\text { Lower expression of DNA fragmen- } \\
\text { tation, activated caspase 3, and } \\
\text { BAX protein in all layers of tertiary } \\
\text { and cystic follicles from COD rats } \\
\text { than in normal atretic follicles from } \\
\text { both groups. Protein expression of } \\
\text { Bcl2, BclxL, and Bclw was high } \\
\text { in healthy and cystic follicles in } \\
\text { both groups }\end{array}$ & $\begin{array}{l}\text { Salvetti et al. } \\
\text { (2009) }\end{array}$ \\
\hline Rat & $\begin{array}{l}\text { DHEA-treated } \\
\text { PCOS rat model }\end{array}$ & $\begin{array}{l}\text { Granulosa cells of } \\
\text { follicular wall of cysts }\end{array}$ & $\begin{array}{l}\text { Immunohistochemistry and } \\
\text { western blot of } \mathrm{Bax} / \mathrm{Bcl} 2\end{array}$ & $\begin{array}{l}\mathrm{Bax} / \mathrm{Bcl} 2 \text { ratio significantly higher in } \\
\text { the ovaries from the PCOS group } \\
\text { than in control group }\end{array}$ & Bas et al. (2011) \\
\hline Mouse & $\begin{array}{l}\text { DHEA-treated } \\
\text { PCOS mouse } \\
\text { model }\end{array}$ & $\begin{array}{l}\text { Complete ovarian } \\
\text { follicles }\end{array}$ & TUNEL & $\begin{array}{l}\text { Increased ovarian apoptosis and larger } \\
\text { follicle size, thereby producing a } \\
\text { characteristic cystic and atretic } \\
\text { appearance in the mouse ovary }\end{array}$ & Kim et al. (1999) \\
\hline Human & $\begin{array}{l}\text { Spontaneous } \\
\text { PCOS }\end{array}$ & $\begin{array}{l}\text { Granulosa cells of } \\
\text { control, ovulatory, } \\
\text { and anovulatory } \\
\text { PCOS patients }\end{array}$ & $\begin{array}{l}\text { Flow cytometry, propidium } \\
\text { iodide non-viable } \\
\text { (apoptotic) cell detection }\end{array}$ & $\begin{array}{l}\text { Most of the granulosa cells of } \\
\text { polycystic ovaries are healthy } \\
\text { and non-apoptotic }\end{array}$ & $\begin{array}{l}\text { Almahbobi et al. } \\
\text { (1996) }\end{array}$ \\
\hline Human & $\begin{array}{l}\text { Spontaneous } \\
\text { PCOS }\end{array}$ & Granulosa cells & $\begin{array}{l}\text { Immunocytochemistry of } \\
\text { activated caspase } 3 \text { and } \\
\text { inhibitor of apoptosis } \\
\text { proteins (IAP), TUNEL, } \\
\text { and Real-time RT-PCR of } \\
\text { IAP and Bcl2 families in } \\
\text { the granulosa cells. The } \\
\text { IAP family included } \\
\text { CIAP1,clAP2, XIAP, and } \\
\text { Survivin. Bcl2 family } \\
\text { members: Bax, Bcl-Long, } \\
\text { and Mcl1 }\end{array}$ & $\begin{array}{l}\text { Decreased expression of DNA frag- } \\
\text { mentation, activated caspase } 3, \\
\text { and BAX protein }\end{array}$ & Das et al. (2008) \\
\hline Bovine & $\begin{array}{l}\text { Spontaneous } \\
\text { COD }\end{array}$ & $\begin{array}{l}\text { Granulosa and theca cells } \\
\text { of healthy antral } \\
\text { follicles, early and late } \\
\text { atretic ones, and early } \\
\text { and late cystic ones }\end{array}$ & TUNEL & $\begin{array}{l}\text { Apoptosis occurs in the granulosa } \\
\text { and theca interna cells of cystic } \\
\text { as well as atretic follicles, but the } \\
\text { frequency of apoptosis in theca } \\
\text { interna cells decreases in late } \\
\text { cystic follicles }\end{array}$ & $\begin{array}{l}\text { Isobe \& Yoshimura } \\
\text { (2000a) }\end{array}$ \\
\hline Bovine & $\begin{array}{l}\text { Spontaneous } \\
\text { COD }\end{array}$ & $\begin{array}{l}\text { Granulosa and theca cells } \\
\text { of follicular cysts }\end{array}$ & $\begin{array}{l}\text { Immunocytochemistry of } \\
\text { activated caspase } 3\end{array}$ & $\begin{array}{l}\text { Decreased expression of activated } \\
\text { caspase } 3\end{array}$ & $\begin{array}{l}\text { Isobe \& Yoshimura } \\
\text { (2007) }\end{array}$ \\
\hline Bovine & $\begin{array}{l}\text { Adrenocortico- } \\
\text { tropin (ACTH)- } \\
\text { induced COD } \\
\text { model }\end{array}$ & $\begin{array}{l}\text { Granulosa and theca cells } \\
\text { of secondary, tertiary, } \\
\text { atretic, and cystic } \\
\text { follicles in ACTH- } \\
\text { induced COD model } \\
\text { and synchronized } \\
\text { control cows }\end{array}$ & $\begin{array}{l}\text { TUNEL, active caspase 3, } \\
\text { FAS/FASLG, and } \\
\text { members of the BCL2 } \\
\text { family by immunohisto- } \\
\text { chemistry and multiplex } \\
\text { PCR }\end{array}$ & $\begin{array}{l}\text { DNA fragmentation, caspase 3, } \\
\text { FASLG, and BAX protein were } \\
\text { significantly less in layers of tertiary } \\
\text { and cystic follicles from COD cows } \\
\text { than in normal atretic follicles of } \\
\text { both groups, whereas BCL2 was } \\
\text { greater in growing and cystic } \\
\text { follicles in both groups. A relatively } \\
\text { greater BCL2 than BAX in cystic } \\
\text { follicles when compared with } \\
\text { tertiary follicles, as indicated by } \\
\text { multiplex analysis }\end{array}$ & $\begin{array}{l}\text { Salvetti et al. } \\
\quad(2010)\end{array}$ \\
\hline Swine & $\begin{array}{l}\text { Spontaneous } \\
\text { COD }\end{array}$ & $\begin{array}{l}\text { Granulosa and theca cells } \\
\text { of normal, atretic, and } \\
\text { cystic follicles }\end{array}$ & $\begin{array}{l}\text { TUNEL, expression of } \\
\text { apoptosis regulators } \\
\text { (XIAP, bax, bc12, and } \\
\text { caspase 3) by immuno- } \\
\text { histochemistry, western } \\
\text { blotting, and real-time } \\
\text { quantitative PCR }\end{array}$ & $\begin{array}{l}\text { Apoptosis levels were high in granu- } \\
\text { losa of atretic follicles, but low in } \\
\text { normal and cystic follicles. In theca } \\
\text { layer, the apoptosis was low in all } \\
\text { follicular categories }\end{array}$ & Sun et al. (2012) \\
\hline
\end{tabular}

PCOS, polycystic ovary syndrome; COD, cystic ovarian disease. 
Additionally, granulosa cells are able to activate endogenous apoptosis pathways in the absence of survival factors (Quirk et al. 2004). For instance, in vitro studies have indicated that in the presence of serum in the culture media, granulosa cells express FAS but are resistant to be killed by exogenous FASLG (Porter et al. 2000, Quirk et al. 2000, 2004, Vickers et al. 2000).

In previous studies conducted in our laboratory, we observed that the immunoexpression of FAS in cyst and atretic follicles is similar, whereas FASLG is only expressed in atretic follicles (Salvetti et al. 2010). These results suggest that, in follicular cysts, reduced apoptosis (which means a delay in atresia) could take place due to the absence of the ligand. On the other hand, dominant follicles are characterized by the presence of survival factors, such as insulin-like growth factor (IGF), which prevent the activation of the FAS pathway and reduce the expression of FAS and FASLG. Furthermore, the ability of growth factors such as IGF1 to facilitate the progression through the cell cycle seems to be a key event to prevent apoptosis. In vitro studies by Quirk et al. (2004) demonstrated that FASLG-induced apoptosis as well as proliferation in granulosa cells can be stimulated by IGF1, basic fibroblast growth factor, and epidermal growth factor. Conversely, the treatment with gonadotropins seems to decrease the expression of deathinducer genes and stimulate the expression of death repressor genes. Specifically, gonadotropins inhibit cell apoptosis and follicular atresia probably via a reduction in BAX in granulosa and maintenance of the constitutive levels of antiapoptotic factors such as BCL2 and BclxL (Tilly 1996).

Ovarian signaling, mainly mediated by steroid hormones and local growth factors, might also play an important role in the balance between proliferation and apoptosis of granulosa cells via regulation of $B C L 2$ and BCL2L1 gene expression (Tilly et al. 1991, Johnson 2003). Regarding BAX, a protein with pro-apoptotic effects, it has been shown that Bax knockout mice develop an excessive number of granulosa cells in their abnormal follicles (Knudson et al. 1995).

Cows with COD show a decrease in the index of proliferation in granulosa and theca cell layers of cystic follicles, similar to that observed in atretic follicles. Previous studies found that the mRNA levels for cyclins D1 and E in samples of the follicular wall are lower in cystic follicles than in healthy tertiary follicles (Isobe \& Yoshimura 2007, Salvetti et al. 2010). Similarly to the results found in induced follicular cysts in rats in different experimental models (Table 1; Baravalle et al. 2006, 2007, Salvetti et al. 2009), tertiary follicles of cows show an intense proliferation in the basal area of the granulosa layer, whereas in atretic and cystic follicles proliferation declines (Isobe \& Yoshimura 2007, Salvetti et al. 2010).

In addition, results from different studies performed in our laboratory suggest that the expression of different markers of apoptosis, such as BAX, FASLG, caspase 3, and DNA fragmentation, is significantly higher in normal atretic follicles than in cystic and tertiary follicles. Conversely, the expression of BCL2 (antiapoptotic) is higher in cysts and growing follicles than in atretic ones (Salvetti et al. 2010). Similar results about apoptosis have been found in ovarian cysts of bovines (Isobe \& Yoshimura 2000b, 2007), as well as in those of rats and other species used as models of COD (Table 2; Anderson \& Lee 1997, Shirwalkar et al. 2007, Salvetti et al. 2009).

In summary, follicular persistence in cystic follicles appears to be related both to reduced apoptosis and to a reduced proliferation rate. The expression of apoptotic markers in follicular cells is related to activation of both the exogenous pathway through death receptors and the endogenous pathway by the BCL2 gene family (Salvetti et al. 2010). However, the poor levels of apoptosis observed in bovine follicular cysts suggest that the activation of both apoptosis pathways is significantly reduced in COD. On the other hand, the balance between proapoptotic and antiapoptotic factors, along with FAS/FASLG, could be influenced by the concentration of different hormones. In this regard, changes in these factors might be induced as a result of altered hormonal levels that characterize COD, and, consequently, cell proliferation and apoptosis might be affected. For example, a reduction in caspase 3 expression could be induced, resulting in decreased apoptosis (Salvetti et al. 2010). All these data support the assumption that, in COD, the expression of proteins related to follicular cell proliferation and apoptosis might be influenced by the hormonal changes characteristic of this disease, contributing to the persistence of cysts.

\section{Conclusions}

Cumulative evidence suggests the existence of multifactorial causes in the pathogenesis of COD. Owing to the lack of a distinct cause of COD, it has been difficult to understand its origins and thus develop an effective treatment. In this sense, considering that ovulation is a complex process where, after initiation by $\mathrm{LH}$, cascades of several pathways interacting within cell types and between cell compartments are involved, any alteration in the multiple links can inhibit it. These processes are essential for the successful establishment of pregnancy, and involve changes in gene expression with overlapping control and interdependent consequences in the theca and granulosa compartments of the ovarian follicle. Systemic and local inputs coordinate with signals from the follicle; thus, ovulation is under multipartite control, facilitating synchronization of oocyte maturation. In this context, interpretation of alterations in endocrine signals through gonadotropins and in paracrine and autocrine signals through steroids is essential for understanding the pathogenesis of COD. A delay in follicle regression after ovulation (by alteration in the proliferation/apoptosis balance) is 
an alternative component in the pathogenesis of cysts because preovulatory follicles that can neither be ovulated nor become atretic will affect the normal ovarian function, being the first step in follicular persistence and establishment of follicular cysts.

\section{Declaration of interest}

The authors declare that there is no conflict of interest that could be perceived as prejudicing the impartiality of the review.

\section{Funding}

Works from the our laboratory cited in this review were funded in part by grants from the Argentine National Agency for the Promotion of Science and Technology (ANPCyT) (PICTs 20071193/2011-1274/2012-2638/2013-2279) and Universidad Nacional del Litoral (CAI+D Program).

\section{References}

Adams GP, Jaiswal R, Singh J \& Malhi P 2008 Progress in understanding ovarian follicular dynamics in cattle. Theriogenology 69 72-80. (doi:10.1016/j.theriogenology.2007.09.026)

Alfaro NS, Salvetti NR, Velázquez MM, Stangaferro ML, Rey F \& Ortega HH 2012 Steroid receptor mRNA expression in the ovarian follicles of cows with cystic ovarian disease. Research in Veterinary Science 92 478-485. (doi:10.1016/j.rvsc.2011.04.009)

Almahbobi G, Anderiesz C, Hutchinson P, McFarlane JR, Wood C \& Trounson AO 1996 Functional integrity of granulosa cells from polycystic ovaries. Clinical Endocrinology 44 571-580.

Amrozi , Kamimura S, Ando T \& Hamana K 2004 Distribution of estrogen receptor $\alpha$ in the dominant follicles and corpus luteum at the three stages of estrous cycle in Japanese black cows. Journal of Veterinary Medical Science 66 1183-1188. (doi:10.1292/jvms.66.1183)

Amweg AN, Salvetti NR, Stangaferro ML, Paredes AH, Lara $\mathbf{H H}$, Rodríguez FM \& Ortega HH 2013 Ovarian localization of $11 \beta$ hydroxysteroid dehydrogenase $(11 \beta \mathrm{HSD})$ : effects of ACTH stimulation and its relationship with bovine cystic ovarian disease. Domestic Animal Endocrinology 45 126-140. (doi:10.1016/j.domaniend.2013.07.001)

Anderson E \& Lee GY 1997 The polycystic ovarian (PCO) condition: apoptosis and epithelialization of the ovarian antral follicles are aspects of cystogenesis in the dehydroepiandrosterone (DHEA)-treated rat model. Tissue \& Cell 29 171-189. (doi:10.1016/S0040-8166(97) 80017-1)

Anderson E, Lee MT \& Lee GY 1992 Cystogenesis of the ovarian antral follicle of the rat: ultrastructural changes and hormonal profile following the administration of dehydroepiandrosterone. Anatomical Record 234 359-382. (doi:10.1002/ar.1092340307)

Anzick SL, Kononen J, Walker RL, Azorsa DO, Tanner MM, Guan XY, Sauter G, Kallioniemi OP, Trent JM \& Meltzer PS 1997 AIB1, a steroid receptor coactivator amplified in breast and ovarian cancer. Science $\mathbf{2 7 7}$ 965-968. (doi:10.1126/science.277.5328.965)

Auger AP \& Jessen HM 2009 Corepressors, nuclear receptors, and epigenetic factors on DNA: a tail of repression. Psychoneuroendocrinology 34 39-47. (doi:10.1016/j.psyneuen.2009.05.012)

Bao B \& Garverick HA 1998 Expression of steroidogenic enzyme and gonadotropin receptor genes in bovine follicles during ovarian follicular waves: a review. Journal of Animal Science 76 1903-1921.

Bao B, Garverick HA, Smith GW, Smith MF, Salfen BE \& Youngquist RS 1997 Changes in messenger ribonucleic acid encoding luteinizing hormone receptor, cytochrome p450-side chain cleavage, and aromatase are associated with recruitment and selection of bovine ovarian follicles. Biology of Reproduction 56 1158-1168. (doi:10.1095/ biolreprod56.5.1158)
Baravalle C, Salvetti NR, Mira GA, Pezzone N \& Ortega HH 2006 Microscopic characterization of follicular structures in letrozole-induced polycystic ovarian syndrome in the rat. Archives of Medical Research 37 830-839. (doi:10.1016/j.arcmed.2006.04.006)

Baravalle C, Salvetti NR, Mira GA, Lorente JA \& Ortega HH 2007 The role of ACTH in the pathogenesis of polycystic ovarian syndrome in rats: hormonal profiles and ovarian morphology. Physiological Research $\mathbf{5 6}$ 67-78.

Bas D, Abramovich D, Hernandez F \& Tesone M 2011 Altered expression of Bcl-2 and Bax in follicles within dehydroepiandrosterone-induced polycystic ovaries in rats. Cell Biology International 35 423-429.

Bautista S, Vallès H, Walker RL, Anzick S, Zeillinger R, Meltzer P \& Theillet C 1998 In breast cancer, amplification of the steroid receptor coactivator gene AIB1 is correlated with estrogen and progesterone receptor positivity. Clinical Cancer Research 4 2925-2929.

Beg MA, Bergfelt DR, Kot K, Wiltbank MC \& Ginther OJ 2001 Follicularfluid factors and granulosa-cell gene expression associated with follicle deviation in cattle. Biology of Reproduction 64 432-441. (doi:10.1095/ biolreprod64.2.432)

Berisha B, Pfaffl M \& Schams D 2002 Expression of estrogen and progesterone receptors in the bovine ovary during estrous cycle and pregnancy. Endocrine 17 207-214. (doi:10.1385/ENDO:17:3:207)

Bhavnani BR, Tam SP \& Lu XF 2008 Structure activity relationships and differential interactions and functional activity of various equine estrogens mediated via estrogen receptors (ERs) ESR1 and ER $\beta$. Endocrinology 149 4857-4870. (doi:10.1210/en.2008-0304)

Bodensteiner KJ, Wiltbank MC, Bergfelt DR \& Ginther OJ 1996 Alterations in follicular estradiol and gonadotropin receptors during development of bovine antral follicles. Theriogenology 45 499-512. (doi:10.1016/0093691X(95)00386-M)

Bramley T 2003 Non-genomic progesterone receptors in the mammalian ovary: some unresolved issues. Reproduction 125 3-15. (doi:10.1530/ rep.0.1250003)

Braw-Tal R \& Roth Z 2005 Gene expression for LH receptor, $17 \alpha$-hydroxylase and StAR in the theca interna of preantral and early antral follicles in the bovine ovary. Reproduction 129 453-461. (doi:10.1530/rep.1.00464)

Brinkmann AO 2001 Lessons to be learned from the androgen receptor. European Journal of Dermatology 11 301-303.

Brosens JJ 2004 Steroid receptor action. Best Practice \& Research. Clinical Obstetrics \& Gynaecology 18 265-283. (doi:10.1016/j.bpobgyn.2004. 01.006)

Calder MD, Manikkam M, Salfen BE, Youngquist RS, Lubahn DB, Lamberson WR \& Garverick HA 2001 Dominant bovine ovarian follicular cysts express increased levels of messenger RNAs for luteinizing hormone receptor and $3 \beta$-hydroxysteroid dehydrogenase delta(4), delta(5) isomerase compared to normal dominant follicles. Biology of Reproduction 65 471-476. (doi:10.1095/biolreprod65.2.471)

Cassar CA, Dow MP, Pursley JR \& Smith GW 2002 Effect of the preovulatory $\mathrm{LH}$ surge on bovine follicular progesterone receptor mRNA expression. Domestic Animal Endocrinology 22 179-187. (doi:10.1016/S07397240(02)00124-8)

Cattaneo L, Signorini M, Bertoli J, Bartolomé J, Gareis N, Díaz P, Bó G \& Ortega H 2014 Epidemiological description of cystic ovarian disease in Argentine dairy herds: risk factors and effects on the reproductive performance of lactating cows. Reproduction in Domestic Animals 49 1028-1033. (doi:10.1111/rda.12432)

Chen JD \& Evans RM 1995 A transcriptional co-repressor that interacts with nuclear hormone receptors. Nature 377 454-457. (doi:10.1038/ 377454a0)

Chen YJ, Lee MT, Yao HC, Hsiao PW, Ke FC \& Hwang JJ 2008 Crucial role of estrogen receptor- $\alpha$ interaction with transcription coregulators in folliclestimulating hormone and transforming growth factor $\beta 1$ up-regulation of steroidogenesis in rat ovarian granulosa cells. Endocrinology 149 4658-4668. (doi:10.1210/en.2008-0063)

Cook DL, Smith CA, Parfet JR, Youngquist RS, Brown EM \& Garverick HA 1990 Fate and turnover rate of ovarian folicular cysts in dairy cattle. Journal of Reproduction and Fertility 90 37-46. (doi:10.1530/jrf.0. 0900037)

Das $M$, Djahanbakhch O, Hacihanefioglu B, Saridogan E, Ikram M, Ghali L, Raveendran M \& Storey A 2008 Granulosa cell survival 
and proliferation are altered in polycystic ovary syndrome. Journal of Clinical Endocrinology and Metabolism 93 881-887. (doi:10.1210/jc. 2007-1650)

Delage-Mourroux R, Martini PG, Choi I, Kraichely DM, Hoeksema J \& Katzenellenbogen BS 2000 Analysis of estrogen receptor interaction with a repressor of estrogen receptor activity (REA) and the regulation of estrogen receptor transcriptional activity by REA. Journal of Biological Chemistry 275 35848-35856. (doi:10.1074/jbc.M001327200)

D'Haeseleer MM, Van den Broeck WL \& Simoens P 2005 Localization of estrogen receptor beta (ERB) mRNA within different bovine ovarian follicles. Anatomia, Histologia, Embryologia 34 14. (doi:10.1111/j.14390264.2005.00669_30.x)

Dobson H, Ribadu AY, Noble KM, Tebble JE \& Ward WR 2000 Ultrasonography and hormone profiles of adrenocorticotrophic hormone (ACTH)-induced persistent ovarian follicles (cysts) in cattle. Journal of Reproduction and Fertility 120 405-410. (doi:10.1530/jrf.0.1200405)

Drummond AE 2006 The role of steroids in follicular growth. Reproductive Biology and Endocrinology 4 16. (doi:10.1186/1477-7827-4-16)

Drummond AE, Britt KL, Dyson M, Jones ME, Kerr JB, O'donnell L, Simpson ER \& Findlay JK 2002 Ovarian steroid receptors and their role in ovarian function. Molecular and Cellular Endocrinology 191 27-33. (doi:10.1016/S0303-7207(02)00052-7)

Evans AC \& Fortune JE 1997 Selection of the dominant follicle in cattle occurs in the absence of differences in the expression of messenger ribonucleic acid for gonadotropin receptors. Endocrinology 138 2963-2971. (doi:10. 1210/endo.138.7.5245)

Evans AC, Ireland JL, Winn ME, Lonergan P, Smith GW, Coussens PM \& Ireland JJ 2004 Identification of genes involved in apoptosis and dominant follicle development during follicular waves in cattle. Biology of Reproduction 70 1475-1484. (doi:10.1095/biolreprod.103.025114)

Evers NM, van den Berg JH, Wang S, Melchers D, Houtman R, de Haan LH, Ederveen AG, Groten JP \& Rietjens IM 2014a Cell proliferation and modulation of interaction of estrogen receptors with coregulators induced by ER $\alpha$ and ER $\beta$ agonists. Journal of Steroid Biochemistry and Molecular Biology 143 376-385. (doi:10.1016/j.jsbmb.2014.06.002)

Evers NM, Wang S, van den Berg JH, Houtman R, Melchers D, de Haan LH, Ederveen AG, Groten JP \& Rietjens IM 2014b Identification of coregulators influenced by estrogen receptor subtype specific binding of the ER antagonists 4-hydroxytamoxifen and fulvestrant. ChemicoBiological Interactions 220 222-230. (doi:10.1016/j.cbi.2014.06.019)

Feng Q \& O'Malley BW 2014 Nuclear receptor modulation - role of coregulators in selective estrogen receptor modulator (SERM) actions. Steroids 90 39-43. (doi:10.1016/j.steroids.2014.06.008)

Fortune JE \& Quirk SM 1988 Regulation of steroidogenesis in bovine preovulatory follicles. Journal of Animal Science 66 1-8.

Fortune JE, Rivera GM, Evans AC \& Turzillo AM 2001 Differentiation of dominant versus subordinate follicles in cattle. Biology of Reproduction 65 648-654. (doi:10.1095/biolreprod65.3.648)

Garverick HA 1997 Ovarian follicular cysts in dairy cows. Journal of Dairy Science 80 995-1004. (doi:10.3168/jds.S0022-0302(97)76025-9)

Garverick HA, Baxter G, Gong J, Armstrong DG, Campbell BK, Gutierrez CG \& Webb R 2002 Regulation of expression of ovarian mRNA encoding steroidogenic enzymes and gonadotrophin receptors by FSH and GH in hypogonadotrophic cattle. Reproduction 123 651-661. (doi:10.1530/rep.0.1230651)

Ginther OJ, Wiltbank MC, Fricke PM, Gibbons JR \& Kot K 1996 Selection of the dominant follicle in cattle. Biology of Reproduction $\mathbf{5 5}$ 1187-1194. (doi:10.1095/biolreprod55.6.1187)

Ginther OJ, Bergfelt DR, Beg MA \& Kot K 2001 Follicle selection in cattle: role of luteinizing hormone. Biology of Reproduction 64 197-205. (doi:10.1095/biolreprod64.1.197)

Goldman S, Weiss A, Almalah I \& Shalev E 2005 Progesterone receptor expression in human decidua and fetal membranes before and after contractions: possible mechanism for functional progesterone withdrawal. Molecular Human Reproduction 11 269-277. (doi:10.1093/ molehr/gah161)

Gougelet A, Mueller SO, Korach KS \& Renoir JM 2007 Oestrogen receptors pathways to oestrogen responsive elements: the transactivation function- 1 acts as the keystone of oestrogen receptor (ER) $\beta$-mediated transcriptional repression of ESR1. Journal of Steroid Biochemistry and Molecular Biology 104 110-122. (doi:10.1016/j. jsbmb.2007.03.002)
Graham JD \& Clarke CL 2002 Expression and transcriptional activity of progesterone receptor $\mathrm{A}$ and progesterone receptor $\mathrm{B}$ in mammalian cells. Breast Cancer Research 4 187-190. (doi:10.1186/bcr450)

Gümen A \& Wiltbank MC 2005 Follicular cysts occur after a normal estradiol-induced $\mathrm{GnRH} / \mathrm{LH}$ surge if the corpus hemorrhagicum is removed. Reproduction 129 737-745. (doi:10.1530/rep.1.00653)

Hall JM \& McDonnell DP 1999 The estrogen receptor b-isoform (ERb) of the human estrogen receptor modulates ERa transcriptional activity and is a key regulator of the cellular response to estrogens and antiestrogens. Endocrinology 140 5566-5578. (doi:10.1210/endo.140.12.7179)

Hamilton SA, Garverick HA, Keisler DH, Xu ZZ, Loos K, Youngqusit RS \& Salfen BE 1995 Characterization of ovarian follicular cysts and associated endocrine profiles in dairy cows. Biology of Reproduction 53 890-898. (doi:10.1095/biolreprod53.4.890)

Hampton JH, Manikkam M, Lubahn DB, Smith MF \& Garverick HA 2004 Androgen receptor mRNA expression in the bovine ovary. Domestic Animal Endocrinology 27 81-88. (doi:10.1016/j.domaniend.2004.01.005)

Hillier SG 2001 Gonadotropic control of ovarian follicular growth and development. Molecular and Cellular Endocrinology 179 39-46. (doi:10.1016/S0303-7207(01)00469-5)

Hillier SG \& Tetsuka M 1997 Role of androgens in follicle maturation and atresia. Baillière's Clinical Obstetrics and Gynaecology 11 249-260. (doi:10.1016/S0950-3552(97)80036-3)

Hlaing M, Nam K, Lou J, Pope WF \& Nephew KP 2001 Evidence for expression of estrogen receptor cofactor messenger ribonucleic acid in the ovary and uterus of domesticated animals (sheep cow and pig). Life Sciences 68 1427-1438. (doi:10.1016/S0024-3205(01)00937-7)

Hörlein AJ, Näär AM, Heinzel T, Torchia J, Gloss B, Kurokawa R, Ryan A, Kamei Y, Söderström M, Glass CK et al. 1995 Ligand-independent repression by the thyroid hormone receptor mediated by a nuclear receptor co-repressor. Nature 377 397-404. (doi:10.1038/377397a0)

Hsueh AJ, Billig H \& Tsafriri A 1994 Ovarian follicle atresia: a hormonally controlled apoptotic process. Endocrine Reviews 15 707-724. (doi:10. 1210/edrv-15-6-707)

Hughes FM Jr \& Gorospe WC 1991 Biochemical identification of apoptosis (programmed cell death) in granulosa cells: evidence for a potential mechanism underlying follicular atresia. Endocrinology 129 2415-2422. (doi:10.1210/endo-129-5-2415)

Hussein-Fikret S \& Fuller PJ 2005 Expression of nuclear receptor coregulators in ovarian stromal and epithelial tumours. Molecular and Cellular Endocrinology 229 149-160. (doi:10.1016/j.mce.2004.08.005)

Ireland JJ \& Roche JF 1983 Development of nonovulatory antral follicles in heifers: changes in steroids in follicular fluid and receptors for gonadotropins. Endocrinology 112 150-156. (doi:10.1210/endo112-1-150)

Isobe N \& Yoshimura Y 2000a Immunocytochemical study of cell proliferation in the cystic ovarian follicles in cows. Theriogenology $\mathbf{5 4}$ 1159-1169. (doi:10.1016/S0093-691X(00)00423-4)

Isobe N \& Yoshimura Y 2000b Localization of apoptotic cells in the cystic ovarian follicles of cows: a DNA-end labeling histochemical study. Theriogenology 53 897-904. (doi:10.1016/S0093-691X(00)00238-7)

Isobe N \& Yoshimura Y 2007 Deficient proliferation and apoptosis in the granulosa and theca interna cells of the bovine cystic follicle. Journal of Reproduction and Development 53 1119-1124. (doi:10.1262/jrd.19041)

Jakimiuk AJ, Weitsman SR, Yen HW, Bogusiewicz M \& Magoffin DA 2002 Estrogen receptor $\alpha$ and $\beta$ expression in theca and granulosa cells from women with polycystic ovary syndrome. Journal of Clinical Endocrinology and Metabolism 87 5532-5538. (doi:10.1210/jc.2002020323)

Jo M, Komar CM \& Fortune JE 2002 Gonadotropin surge induces two separate increases in messenger RNA for progesterone receptor in bovine preovulatory follicles. Biology of Reproduction 67 1981-1988. (doi:10.1095/biolreprod.102.004366)

Johnson AL 2003 Intracellular mechanisms regulating cell survival in ovarian follicles. Animal Reproduction Science 78 185-201. (doi:10.1016/S0378-4320(03)00090-3)

Kawate N 2004 Studies on the regulation of expression of luteinizing hormone receptor in the ovary and the mechanism of follicular cyst formation in ruminants. Journal of Reproduction and Development $\mathbf{5 0}$ 1-8. (doi:10.1262/jrd.50.1) 
Kawate N, Inaba T \& Mori J 1990 A quantitative comparison in the bovine of steroids and gonadotropin receptors in normally developing follicles and in follicular and luteinized cysts. Animal Reproduction Science 23 273-281. (doi:10.1016/0378-4320(90)90041-D)

Kawate N, Inaba T \& Mori J 1996 Changes in plasma concentrations of gonadotropins and steroid hormones during the formation of bovine follicular cysts induced by the administration of ACTH. Journal of Veterinary Medical Science 58 141-144. (doi:10.1292/jvms.58.141)

Kawate N, Akiyama M, Suga T, Inaba T, Tamada H, Sawada T \& Mori J 2001 Change in concentrations of luteinizing hormone subunit messenger ribonucleic acids in the estrous cycle of beef cattle. Animal Reproduction Science 68 13-21. (doi:10.1016/S0378-4320(01)00132-4)

Kesler DJ \& Garverick HA 1982 Ovarian cysts in dairy cattle: a review. Journal of Animal Science 55 1147-1159. (doi:10.2134/jas1982. $5551147 x$ )

Kim JH, Han JS \& Yoon YD 1999 Biochemical and morphological identification of ceramide-induced cell cycle arrest and apoptosis in cultured granulosa cells. Tissue \& Cell 31 531-539. (doi:10.1054/tice. 1999.0061)

Kimura S, Matsumoto T, Matsuyama R, Shiina H, Sato T, Takeyama K \& Kato S 2007 Androgen receptor function in folliculogenesis and its clinical implication in premature ovarian failure. Trends in Endocrinology and Metabolism 18 183-189. (doi:10.1016/j.tem.2007. 04.002)

Knudson CM, Tung KS, Tourtellotte WG, Brown GA \& Korsmeyer SJ 1995 Bax-deficient mice with lymphoid hyperplasia and male germ cell death. Science 270 96-99. (doi:10.1126/science.270.5233.96)

Krammer PH 1999 CD95(APO-1/Fas)-mediated apoptosis: live and let die. Advances in Immunology 71 163-210. (doi:10.1016/S0065-2776 (08)60402-2)

Kuiper GG, Enmark E, Pelto-Huikko M, Nilsson S \& Gustafsson JA 1996 Cloning of a novel receptor expressed in rat prostate and ovary. PNAS 93 5925-5930. (doi:10.1073/pnas.93.12.5925)

Kurtev V, Margueron R, Kroboth K, Ogris E, Cavailles V \& Seiser C 2004 Transcriptional regulation by the repressor of estrogen receptor activity via recruitment of histone deacetylases. Journal of Biological Chemistry 279 24834-24843. (doi:10.1074/jbc.M312300200)

Liptrap RM 1993 Stress and reproduction in domestic animals. Annals of the New York Academy of Sciences 697 275-284. (doi:10.1111/j.17496632.1993.tb49941.x)

Liptrap RM \& McNally PJ 1976 Steroid concentrations in cows with corticotropin-induced cystic ovarian follicles and the effect of prostaglandin $\mathrm{F}_{2 \alpha}$ and indomethacin given by intrauterine injection. American Journal of Veterinary Research 37 369-375.

Luo W \& Wiltbank MC 2006 Distinct regulation by steroids of messenger RNAs for FSHR and CYP19A1 in bovine granulosa cells. Biology of Reproduction 75 217-225. (doi:10.1095/biolreprod.105.047407)

Manikkam M, Calder MD, Salfen BE, Youngquist RS, Keisler DH \& Garverick HA 2001 Concentrations of steroids and expression of messenger RNA for steroidogenic enzymes and gonadotropin receptors in bovine ovarian follicles of first and second waves and changes in second wave follicles after pulsatile LH infusion. Animal Reproduction Science 67 189-203. (doi:10.1016/S0378-4320(01)00120-8)

Marelli BE, Díaz PU, Salvetti NR, Rey F \& Ortega HH 2014 mRNA expression pattern of gonadotropin receptors in bovine follicular cysts. Reproductive Biology 14 276-281. (doi:10.1016/j.repbio.2014.08.002)

Markstrom E, Svensson EC, Shao R, Svanberg B \& Billig H 2002 Survival factors regulating ovarian apoptosis - dependence on follicle differentiation. Reproduction 123 23-30. (doi:10.1530/rep.0.1230023)

Martini PG, Delage-Mourroux R, Kraichely DM \& Katzenellenbogen BS 2000 Prothymosin $\alpha$ selectively enhances estrogen receptor transcriptional activity by interacting with a repressor of estrogen receptor activity. Molecular and Cellular Biology 20 6224-6232. (doi:10.1128/MCB.20. 17.6224-6232.2000)

Matiller V, Stangaferro ML, Díaz PU, Ortega HH, Rey F, Huber E \& Salvetti NR 2014 Altered expression of transforming growth factor- $\beta$ isoforms in bovine cystic ovarian disease. Reproduction in Domestic Animals 49 813-823. (doi:10.1111/rda.12373)

McInerney EM, Weis KE, Sun J, Mosselman S \& Katzenellenbogen BS 1998 Transcription activation by the human estrogen receptor subtype beta (ER $\beta$ ) studied with ER $\beta$ and ER $\alpha$ receptor chimeras. Endocrinology 139 4513-4522. (doi:10.1210/en.139.11.4513)
McKenna NJ, Lanz RB \& O'Malley BW 1999 Nuclear receptor coregulators: cellular and molecular biology. Endocrine Reviews 20 321-344. (doi:10. 1210/edrv.20.3.0366)

Mihm M, Baguisi A, Boland MP \& Roche JF 1994 Association between the duration of dominance of the ovulatory follicle and pregnancy rate in beef heifers. Journal of Reproduction and Fertility 102 123-130. (doi:10.1530/jrf.0.1020123)

Mihm M, Baker PJ, Ireland JL, Smith GW, Coussens PM, Evans AC \& Ireland J 2006 Molecular evidence that growth of dominant follicles involves a reduction in follicle-stimulating hormone dependence and an increase in luteinizing hormone dependence in cattle. Biology of Reproduction 74 1051-1059. (doi:10.1095/biolreprod.105.045799)

Misiti S, Schomburg L, Yen PM \& Chin WW 1998 Expression and hormonal regulation of coactivator and corepressor genes. Endocrinology 139 2493-2500. (doi:10.1210/endo.139.5.5971)

Misiti S, Koibuchi N, Bei M, Farsetti A \& Chin WW 1999 Expression of steroid receptor coactivator- 1 mRNA in the developing mouse embryo: a possible role in olfactory epithelium development. Endocrinology 140 1957-1960. (doi:10.1210/endo.140.4.6782)

Moberg GP 1987 Influence of the adrenal axis upon the gonads. Journal of Animal Science 65 1228-1235. (doi:10.2134/jas1987.6551228x)

Montano MM, Ekena K, Delage-Mourroux R, Chang W, Martini P \& Katzenellenbogen BS 1999 An estrogen receptor-selective coregulator that potentiates the effectiveness of antiestrogens and represses the activity of estrogens. PNAS 96 6947-6952. (doi:10.1073/pnas.96.12.6947)

Mosselman S, Polman J \& Dijkema R 1996 ERß: identification and characterization of a novel human estrogen receptor. FEBS Letters 392 49-53. (doi:10.1016/0014-5793(96)00782-X)

Mukherjee A, Amato P, Allred DC, DeMayo FJ \& Lydon JP 2007 Steroid receptor coactivator 2 is required for female fertility and mammary morphogenesis: insights from the mouse, relevance to the human. Nuclear Receptor Signaling 5 e011. (doi:10.1621/nrs.05011)

Mussi P, Liao L, Park S, Ciana P, Maggi A, Katzenellenbogen BS, Xu J \& O'Malley BW 2006 Haploinsufficiency of the corepressor of estrogen receptor activity (REA) enhances estrogen receptor function in the mammary gland. PNAS 103 16716-16721. (doi:10.1073/pnas. 0607768103)

Nephew KP, Ray S, Hlaing M, Ahluwalia A, Wu SD, Long X, Hyder SM \& Bigsby RM 2000 Expression of estrogen receptor coactivators in the rat uterus. Biology of Reproduction 63 361-367. (doi:10.1095/biolreprod63.2.361)

Nimz M, Spitschak M, Schneider F, Fürbass R \& Vanselow J 2009 Downregulation of genes encoding steroidogenic enzymes and hormone receptors in late preovulatory follicles of the cow coincides with an accumulation of intrafollicular steroids. Domestic Animal Endocrinology 37 45-54. (doi:10.1016/j.domaniend.2009.02.002)

Nogueira MF, Buratini J, Price CA, Castilho AC, Pinto MG \& Barros CM 2007 Expression of $\mathrm{LH}$ receptor mRNA splice variants in bovine granulosa cells: changes with follicle size and regulation by $\mathrm{FSH}$ in vitro. Molecular Reproduction and Development 74 680-686. (doi:10. 1002/mrd.20656)

Nogueira MF, Fernandes P, Ereno RL, Simoes RA, Buratoni J \& Barros CM 2010 Luteinizing Hormone Receptor (LHR): basic concepts in cattle and other mammals. A review. Animal Reproduction 7 51-64.

O'Brien ML, Park K, In Y \& Park-Sarge OK 1999 Characterization of estrogen receptor-beta (ER $\beta)$ messenger ribonucleic acid and protein expression in rat granulosa cells. Endocrinology 140 4530-4541. (doi:10.1210/en.140.10.4530)

Odore R, Re G, Badino P, Donn A, Vigo D, Biolatti B \& Girardi C 1999 Modifications of receptor concentrations for adrenaline, steroid hormones, prostaglandin $\mathrm{F}_{2 \alpha}$ and gonadotropins in hypophysis and ovary of dairy cows with ovarian cysts. Pharmacological Research 39 297-304. (doi:10.1006/phrs.1998.0442)

Ortega HH, Salvetti NR, Amable P, Dallard BE, Baravalle C, Barbeito CG \& Gimeno EJ 2007 Intraovarian localization of growth factors in induced cystic ovaries in rats. Anatomia, Histologia, Embryologia 36 94-102. (doi:10.1111/j.1439-0264.2006.00726.x)

Ortega HH, Palomar MM, Acosta JC, Salvetti NR, Dallard BE, Lorente JA, Barbeito CG \& Gimeno EJ 2008 Insulin-like growth factor I in ovarian follicles and follicular fluid of cows with spontaneous and induced cystic ovarian disease. Research in Veterinary Science 84 419-427. (doi:10. 1016/j.rvsc.2007.05.010) 
Ortega HH, Salvetti NR \& Padmanabhan V 2009 Developmental programming: prenatal androgen excess disrupt ovarian steroid receptor balance. Reproduction 137 865-877. (doi:10.1530/REP-08-0491)

Park SE, Xu J, Frolova A, Liao L, O'Malley BW \& Katzenellenbogen BS 2005 Genetic deletion of the repressor of estrogen receptor activity (REA) enhances the response to estrogen in target tissues in vivo. Molecular and Cellular Biology 25 1989-1999. (doi:10.1128/MCB.25. 5.1989-1999.2005)

Peter AT 2004 An update on cystic ovarian degeneration in cattle. Reproduction in Domestic Animals 39 1-7. (doi:10.1046/j.0936-6768. 2003.00466.x)

Pettersson K, Grandien K, Kuiper GG \& Gustafsson JA 1997 Mouse estrogen receptor $\beta$ forms estrogen response element-binding heterodimers with estrogen receptor $\alpha$. Molecular Endocrinology 11 1486-1496. (doi:10. 1210/mend.11.10.9989)

Pettersson K, Delaunay F \& Gustafsson JA 2000 Estrogen receptor $\beta$ acts as a dominant regulator of estrogen signaling. Oncogene 19 4970-4978. (doi:10.1038/sj.onc.1203828)

Porter DA, Vickers SL, Cowan RG, Huber SC \& Quirk SM 2000 Expression and function of Fas antigen vary in bovine granulosa and theca cells during ovarian follicular development and atresia. Biology of Reproduction 62 62-66. (doi:10.1095/biolreprod62.1.62)

Porter DA, Harman RM, Cowan RG \& Quirk SM 2001 Susceptibility of ovarian granulosa cells to apoptosis differs in cells isolated before or after the preovulatory LH surge. Molecular and Cellular Endocrinology 176 13-20. (doi:10.1016/S0303-7207(01)00479-8)

Quirk SM, Harman RM \& Cowan RG 2000 Regulation of Fas antigen (Fas, CD95)-mediated apoptosis of bovine granulosa cells by serum and growth factors. Biology of Reproduction 63 1278-1284. (doi:10.1095/ biolreprod63.5.1278

Quirk SM, Cowan RG, Harman RM, Hu CL \& Porter DA 2004 Ovarian follicular growth and atresia: the relationship between cell proliferation and survival. Journal of Animal Science 82 E40-E52.

Rajapaksha WR, Robertson L \& O'Shaughnessy PJ 1996 Expression of follicle-stimulating hormone-receptor mRNA alternate transcripts in bovine granulose cells during luteinization in vivo and in vitro. Molecular and Cellular Endocrinology 120 25-30. (doi:10.1016/03037207(96)03816-6)

Reed SI 1996 Cyclin E: in mid-cycle. Biochimica et Biophysica Acta 1287 151-153. (doi:10.1016/0304-419X(96)00006-6)

Robert C, Gagne D, Lussier JG, Bousquet D, Barnes FL \& Sirard MA 2003 Presence of $\mathrm{LH}$ receptor mRNA in granulosa cells as a potential marker of oocyte developmental competence and characterisation of the bovine splicing isoforms. Reproduction 125 437-446. (doi:10.1530/ rep.0.1250437)

Robker RL \& Richards JS 1998a Hormonal control of the cell cycle in ovarian cells: proliferation versus differentiation. Biology of Reproduction 59 476-482. (doi:10.1095/biolreprod59.3.476)

Robker RL \& Richards JS 1998b Hormone-induced proliferation and differentiation of granulosa cells: a coordinated balance of the cell cycle regulators cyclin D2 and p27Kip1. Molecular Endocrinology 12 924-940. (doi:10.1210/mend.12.7.0138)

Rosenfeld CS, Wagner JS, Roberts RM \& Lubahn DB 2001 Intraovarian actions of oestrogen. Reproduction 122 215-226. (doi:10.1530/rep.0. 1220215)

Roughton SA, Lareu RR, Bittles AH \& Dharmarajan AM 1999 Fas and Fas ligand messenger ribonucleic acid and protein expression in the rat corpus luteum during apoptosis-mediated luteolysis. Biology of Reproduction 60 797-804. (doi:10.1095/biolreprod60.4.797)

Salvetti NR, Acosta JC, Gimeno EJ, Muller LA, Mazzini RA, Taboada AF \& Ortega HH 2007 Estrogen receptors $\alpha$ and $\beta$ and progesterone receptors in normal bovine ovarian follicles and cystic ovarian disease. Veterinary Pathology 44 373-378. (doi:10.1354/vp.44-3-373)

Salvetti NR, Panzani CG, Gimeno EJ, Neme LG, Alfaro NS \& Ortega HH 2009 An imbalance between apoptosis and proliferation contributes to follicular persistence in polycystic ovaries in rats. Reproductive Biology and Endocrinology 7 68. (doi:10.1186/1477-7827-7-68)

Salvetti NR, Stangaferro ML, Palomar MM, Alfaro NS, Rey F, Gimeno EJ \& Ortega HH 2010 Cell proliferation and survival mechanisms underlying the abnormal persistence of follicular cysts in bovines with cystic ovarian disease induced by ACTH. Animal Reproduction Science 122 98-110. (doi:10.1016/j.anireprosci.2010.08.003)
Salvetti NR, Alfaro NS, Velázquez MM, Amweg AN, Matiller V, Díaz PU \& Ortega HH 2012 Alteration in localization of steroid hormone receptors and coregulatory proteins in follicles from cows with induced ovarian follicular cysts. Reproduction 144 723-735. (doi:10.1530/REP-12-0188)

Sartori R, Fricke PM, Ferreira JC, Ginther OJ \& Wiltbank MC 2001 Follicular deviation and acquisition of ovulatory capacity in bovine follicles. Biology of Reproduction 65 1403-1409. (doi:10.1095/biolreprod65.5.1403)

Sarvilinna N, Eronen H, Miettinen S, Vienonen A \& Ylikomi T 2006 Steroid hormone receptors and coregulators in endocrine-resistant and estrogenindependent breast cancer cells. International Journal of Cancer $\mathbf{1 1 8}$ 832-840. (doi:10.1002/ijc.21431)

Scaffidi C, Fulda S, Srinivasan A, Friesen C, Li F, Tomaselli KJ, Debatin KM, Krammer PH \& Peter ME 1998 Two CD95 (APO-1/Fas) signaling pathways. EMBO Journal 17 1675-1687. (doi:10.1093/emboj/17.6.1675)

Schams D \& Berisha B 2002 Steroids as local regulators of ovarian activity in domestic animals. Domestic Animal Endocrinology 23 53-65. (doi:10.1016/S0739-7240(02)00145-5)

Schams D, Kohlenberg S, Amselgruber W, Berisha B, Pfaffl MW \& Sinowatz F 2003 Expression and localisation of oestrogen and progesterone receptors in the bovine mammary gland during development, function and involution. Journal of Endocrinology 177 305-317. (doi:10.1677/joe.0.1770305)

Segaloff DL \& Ascoli M 1993 The lutropin/choriogonadotropin receptor ... 4 years later. Endocrine Reviews 14 324-347. (doi:10.1210/edrv14-3-324)

Segaloff DL, Sprengel R, Nikolics K \& Ascoli M 1990 Structure of the lutropin/choriogonadotropin receptor. Recent Progress in Hormone Research 46 261-303.

Sette C, Messina V \& Paronetto MP 2010 Sam68: a new STAR in the male review fertility firmament. Journal of Andrology 31 66-74. (doi:10.2164/ jandrol.109.008136)

Shirwalkar H, Modi DN \& Maitra A 2007 Exposure of adult rats to estradiol valerate induces ovarian cyst with early senescence of follicles. Molecular and Cellular Endocrinology 272 22-37. (doi:10.1016/j.mce. 2007.04.003)

Shushan A, Peretz T, Uziely B, Lewin A \& Mor-Yosef S 1996 Ovarian cysts in premenopausal and postmenopausal tamoxifen-treated women with breast cancer. American Journal of Obstetrics and Gynecology 174 141-144. (doi:10.1016/S0002-9378(96)70386-1)

Silvia WJ, Hatler TB, Nugent AM \& Laranja da Fonseca LF 2002 Ovarian follicular cysts in dairy cows: an abnormality in folliculogenesis. Domestic Animal Endocrinology 23 167-177. (doi:10.1016/S07397240(02)00154-6)

Simoni M, Gromoll J \& Nieschlag E 1997 The follicle-stimulating hormone receptor: biochemistry, molecular biology, physiology, and pathophysiology. Endocrine Reviews 18 739-773. (doi:10.1210/edrv.18.6.0320)

Slot KA, Voorendt M, de Boer-Brouwer M, van Vugt HH \& Teerds KJ 2006 Estrous cycle dependent changes in expression and distribution of Fas, Fas ligand, Bcl-2, Bax, and pro- and active caspase-3 in the rat ovary. Journal of Endocrinology 188 179-192. (doi:10.1677/joe.1.06165)

Soumano K, Lussier JG \& Price CA 1998 Levels of messenger RNA encoding ovarian receptors for $\mathrm{FSH}$ and $\mathrm{LH}$ in cattle during superovulation with equine chorionic gonadotrophin versus FSH. Journal of Endocrinology 156 373-378. (doi:10.1677/joe.0.1560373)

Sun YL, Zhang J, Ping ZG, Wang CQ, Sun YF, Chen L, Li XY, Li CJ, Zhu XL, Liu Z et al. 2012 Relationship between apoptosis and proliferation in granulosa and theca cells of cystic follicles in sows. Reproduction in Domestic Animals 47 601-608. (doi:10.1111/j.1439-0531.2011. 01929.x)

Szwarc MM, Kommagani R, Jeong JW, Wu SP, Tsai SY, Tsai MJ, O'Malley BW, DeMayo FJ \& Lydon JP 2014 Perturbing the cellular levels of steroid receptor coactivator-2 impairs murine endometrial function. PLOS ONE 9 e98664. (doi:10.1371/journal.pone.0098664)

Takeo J \& Yamashita S 1999 Two distinct isoforms of cDNA encoding rainbow trout androgen receptors. Journal of Biological Chemistry $\mathbf{2 7 4}$ 5674-5680. (doi:10.1074/jbc.274.9.5674)

Tanner MM, Grenman S, Koul A, Johannsson O, Meltzer P, Pejovic T, Borg ̊̊ \& Isola JJ 2000 Frequent amplification of chromosomal region 20q12-q13 in ovarian cancer. Clinical Cancer Research 6 1833-1839.

Tilly JL 1996 Apoptosis and ovarian function. Reviews of Reproduction $\mathbf{1}$ 162-172. (doi:10.1530/ror.0.0010162) 
Tilly JL, Kowalski KI, Johnson AL \& Hsueh AJ 1991 Involvement of apoptosis in ovarian follicular atresia and postovulatory regression. Endocrinology 129 2799-2801. (doi:10.1210/endo-129-5-2799)

Van den Broeck W, Coryn M, Simoens P \& Lauwers H 2002a Cell-specific distribution of oestrogen receptor- $\alpha$ in the bovine ovary. Reproduction in Domestic Animals 37 291-293. (doi:10.1046/j.1439-0531.2002.00352.x)

Van den Broeck W, D'Haeseleer M, Coryn M \& Simoens P 2002b Cellspecific distribution of progesterone receptors in the bovine ovary. Reproduction in Domestic Animals 37 314-320. (doi:10.1046/j.14390531.2002.00366.x)

Vanholder T, Opsomer G \& De Kruif A 2006 Aetiology and pathogenesis of cystic ovarian follicles in dairy cattle: a review. Reproduction, Nutrition, Development 46 105-119. (doi:10.1051/rnd:2006003)

Vassart G, Pardo L \& Costagliola S 2004 A molecular dissection of the glycoprotein hormone receptors. Trends in Biochemical Sciences 29 119-126. (doi:10.1016/j.tibs.2004.01.006)

Vegeto E, Shahbaz MM, Wen DX, Goldman ME, O'Malley BW \& McDonnell DP 1993 Human progesterone receptor A form is a celland promoter-specific repressor of human progesterone receptor $B$ function. Molecular Endocrinology 7 1244-1255. (doi:10.1210/mend.7. 10.8264658)

Velázquez MM, Alfaro NS, Dupuy CR, Salvetti NR, Rey F \& Ortega HH 2010 Heat shock protein patterns in the bovine ovary and relation with cystic ovarian disease. Animal Reproduction Science 118 201-209. (doi:10.1016/j.anireprosci.2009.08.010)

Velázquez MM, Alfaro NS, Salvetti NR, Stangaferro ML, Rey F, Panzani CG \& Ortega HH 2011 Levels of heat shock protein transcripts in normal follicles and ovarian follicular cysts. Reproductive Biology 11 276-283.

Vendola KA, Zhou J, Adesanya OO, Weil SJ \& Bondy CA 1998 Androgens stimulate early stages of follicular growth in the primate ovary. Journal of Clinical Investigation 15 2622-2629. (doi:10.1172/JCI2081)

Vickers SL, Cowan RG, Harman RM, Porter DA \& Quirk SM 2000 Expression and activity of the Fas antigen in bovine ovarian follicle cells. Biology of Reproduction 62 54-61. (doi:10.1095/biolreprod62.1.54)

Walters KA, Allan CM \& Handelsman DJ 2008 Androgen actions and the ovary. Biology of Reproduction 78 380-389. (doi:10.1095/biolreprod. 107.064089)

Wei LL, Gonzalez-Aller C, Wood WM, Miller LA \& Horwitz KB 1990 $5^{\prime}$-Heterogeneity in human progesterone receptor transcripts predicts a new amino-terminal truncated " $\mathrm{C}$ "-receptor and unique A-receptor messages. Molecular Endocrinology 4 1833-1840. (doi:10.1210/mend4-12-1833)
Wei LL, Norris BM \& Baker CJ 1997 An N-terminally truncated third progesterone receptor protein, $\mathrm{PR}(\mathrm{C})$, forms heterodimers with $\mathrm{PR}(\mathrm{B})$ but interferes in PR(B)-DNA binding. Journal of Steroid Biochemistry and Molecular Biology 62 287-297. (doi:10.1016/S0960-0760(97)00044-7)

Wiltbank MC, Gümen A \& Sartori R 2002 Physiological classification of anovulatory conditions in cattle. Theriogenology 57 21-52.

Wu RC, Qin J, Hashimoto Y, Wong J, Xu J, Tsai SY, Tsai MJ \& O'Malley BW 2002 Regulation of NCOA3 (pCIP/ACTR/AIB-1/RAC-3/TRAM-1) coactivator activity by I kappa B kinase. Molecular and Cellular Biology 22 3549-3561. (doi:10.1128/MCB.22.10.3549-3561.2002)

Xu Z, Garverick HA, Smith GW, Smith MF, Hamilton SA \& Youngquist RS 1995 Expression of follicle-stimulating hormone and luteinizing hormone receptor messenger ribonucleic acids in bovine follicles during the first follicular wave. Biology of Reproduction 53 951-957. (doi:10. 1095/biolreprod53.4.951)

Xu J, Qiu Y, DeMayo FJ, Tsai SY, Tsai MJ \& O’Malley BW 1998 Partial hormone resistance in mice with disruption of the steroid receptor coactivator-1 (NCOA1) gene. Science 279 1922-1925. (doi:10.1126/ science.279.5358.1922)

Yamauchi N, Takezawa T, Kizaki K, Herath CB \& Hashizume K 2003 Proliferative potential of endometrial stromal cells, and endometrial and placental expression of cyclin in the bovine. Journal of Reproduction and Development 49 553-560. (doi:10.1262/jrd.49.553)

Yang Z, Wolf IM, Chen H, Periyasamy S, Chen Z, Yong W, Shi S, Zhao W, Xu J \& Srivastava A 2006 FK506-binding protein 52 is essential to uterine reproductive physiology controlled by the progesterone receptor $\mathrm{A}$ isoform. Molecular Endocrinology 20 2682-2694. (doi:10.1210/me.2006-0024)

Zhang H, Liao L, Kuang SQ \& Xu J 2003 Spatial distribution of the messenger ribonucleic acid and protein of the nuclear receptor coactivator, amplified in breast cancer-3, in mice. Endocrinology 144 1435-1443. (doi:10.1210/en.2002-0018)

Zwijsen RM, Wientjens E, Klompmaker R, van der Sman J, Bernards R \& Michalides RJ 1997 CDK-independent activation of estrogen receptor by cyclin D1. Cell 88 405-415. (doi:10.1016/S0092-8674 (00)81879-6)

Received 1 September 2014

First decision 13 October 2014

Revised manuscript received 25 February 2015

Accepted 12 March 2015 